4

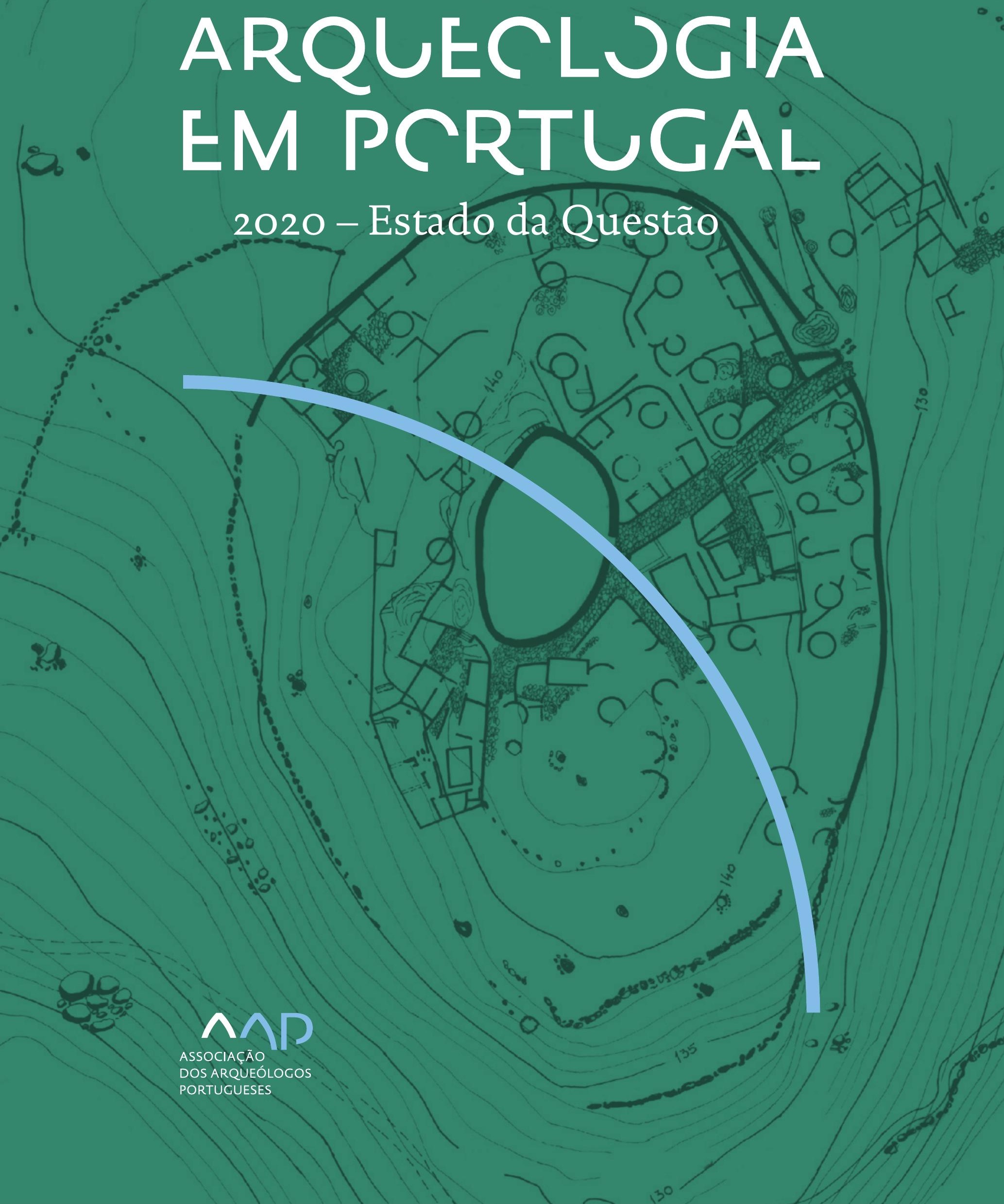


Coordenação editorial: José Morais Arnaud, César Neves e Andrea Martins Design gráfico: Flatland Design

AAP - ISBN: 978-972-9451-89-8

CITCEM - ISBN: 978-989-8970-25-1

Associação dos Arqueólogos Portugueses e CITCEM

Lisboa, 2020

O conteúdo dos artigos é da inteira responsabilidade dos autores. Sendo assim a Associação dos Arqueólogos Portugueses declina qualquer responsabilidade por eventuais equívocos ou questões de ordem ética e legal.

Desenho de capa:

Planta do castro de Monte Mozinho (Museu Municipal de Penafiel).

\section{$\hat{\wedge} \mathrm{P}$}

DOS ARQUEÓLOGOS PORTUGUESES

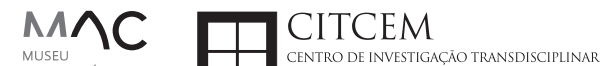
MUSEU
ARQUELLÓGICO
DO CARMO
U.PORTO

FLUP FACULDADE DE LETRAS
UNIVERSIDADE DO PORTO

Apoio

EC para a Ciência 


\section{Índice}

15 Prefácio

José Morais Arnaud

\section{Historiografia e Teoria}

17 Território, comunidade, memória e emoção: a contribuição da história da arqueologia (algumas primeiras e breves reflexões)

Ana Cristina Martins

25 Como descolonizar a arqueologia portuguesa?

Rui Gomes Coelho

41 Arqueologia e Modernidade: uma revisitação pessoal e breve de alguns aspetos da obra homónima de Julian Thomas de 2004

Vítor Oliveira Jorge

57 Dados para a História das Mulheres na Arqueologia portuguesa, dos finais do século XIX aos inícios do século XX: números, nomes e tabelas

Filipa Dimas / Mariana Diniz

73 Retractos da arqueologia portuguesa na imprensa: (in)visibilidades no feminino

Catarina Costeira / Elsa Luís

85 Arqueologia e Arqueólogos no Norte de Portugal Jacinta Bugalhão

101 Vieira Guimarães (1864-1939) e a arqueologia em Tomar: uma abordagem sobre o território e as gentes

João Amendoeira Peixoto / Ana Cristina Martins

115 Os memoráveis? A arqueologia algarvia na imprensa nacional e regional na presente centúria (2001-2019): características, visões do(s) passado(s) e a arqueologia

enquanto marca

Frederico Agosto / João Silva

129 A Evolução da Arqueologia Urbana e a Valorização Patrimonial no Barlavento Algarvio: Os casos de Portimão e Silves

Artur Mateus / Diogo Varandas / Rafael Boavida

\section{Gestão, Valorização e Salvaguarda do Património}

145 O Caderno Reivindicativo e as condições de trabalho em Arqueologia Miguel Rocha / Liliana Matias Carvalho / Regis Barbosa / Mauro Correia / Sara Simões / Jacinta Bugalhão / Sara Brito / Liliana Veríssimo Carvalho / Richard Peace / Pedro Peça / Cézer Santos

155 Os Estudos de Impacte Patrimonial como elemento para uma estratégia sustentável de minimização de impactes no âmbito de reconversões agrícolas Tiago do Pereiro

165 Salvaguarda de Património arqueológico em operações florestais: gestão e sensibilização Filipa Bragança / Gertrudes Zambujo / Sandra Lourenço / Belém Paiva / Carlos Banha / Frederico Tatá Regala / Helena Moura / Jacinta Bugalhão / João Marques / José Correia / Pedro Faria / Samuel Melro

179 Os valores do Património: uma investigação sobre os Sítios Pré-históricos de Arte Rupestre do Vale do Rio Côa e de Siega Verde José Paulo Francisco 
189 Conjugando recursos arqueológicos e naturais para potenciar as visitas ao Geoparque Litoral de Viana do Castelo (Noroeste de Portugal)

Hugo A. Sampaio / Ana M.S. Bettencourt / Susana Marinho / Ricardo Carvalhido

203 Áreas de Potencial Arqueológico na Região do Médio Tejo: Modelo Espacial Preditivo Rita Ferreira Anastácio / Ana Filipa Martins / Luiz Oosterbeek

223 Património Arqueológico e Gestão Territorial: O contributo da Arqueologia para a revisão do PDM de Avis

Ana Cristina Ribeiro

237 A coleção arqueológica do extinto Museu Municipal do Porto - Origens, Percursos e Estudos

Sónia Couto

251 Valpaços - uma nova carta arqueológica

Pedro Pereira / Maria de Fátima Casares Machado

263 Arqueologia na Cidade de Peniche

Adriano Constantino / Luís Rendeiro

273 Arqueologia Urbana: a cidade de Lagos como caso de Estudo Cátia Neto

285 Estratégias de promoção do património cultural subaquático nos Açores. O caso da ilha do Faial

José Luís Neto / José Bettencourt / Luís Borges / Pedro Parreira

297 Carta Arqueológica da Cidade Velha: Uma primeira abordagem

Jaylson Monteiro / Nireide Tavares / Sara da Veiga / Claudino Ramos / Edson Brito /

Carlos Carvalho / Francisco Moreira / Adalberto Tavares

311 Antropologia Virtual: novas metodologias para a análise morfológica e funcional Ricardo Miguel Godinho / Célia Gonçalves

\section{Didáctica da Arqueologia}

327 Como os projetos de Arqueologia podem contribuir para uma comunidade culturalmente mais consciente Alexandra Figueiredo / Claúdio Monteiro / Adolfo Silveira / Ricardo Lopes

337 Educação Patrimonial - Um cidadão esclarecido é um cidadão ativo! Ana Paula Almeida

351 A aproximação da Arqueologia à sala de aula: um caso de estudo no $3^{\circ}$ ciclo do Ensino Básico Luís Serrão Gil

363 Arqueologia 3.o - Pensar e comunicar a Arqueologia para um futuro sustentável Mónica Rolo

377 “Conversa de Arqueólogos" - Divulgar a Arqueologia em tempos de Pandemia Diogo Teixeira Dias

389 Escola Profissional de Arqueologia: desafios e oportunidades Susana Nunes / Dulcineia Pinto / Júlia Silva / Ana Mascarenhas

399 Os Museus de Arqueologia e os Jovens: a oferta educativa para o público adolescente Beatriz Correia Barata / Leonor Medeiros

411 O museu universitário como mediador entre a ciência e a sociedade: o exemplo da secção de arqueologia no Museu de História Natural e da Ciência da Universidade do Porto (MHNC-UP)

Rita Gaspar 
421 Museu de Lanifícios: Real Fábrica de Panos. Atividades no âmbito da Arqueologia Beatriz Correia Barata / Rita Salvado

427 Arqueologia Pública e o caso da localidade da Mata (Torres Novas) Cláudia Manso / Ana Rita Ferreira / Cristiana Ferreira / Vanessa Cardoso Antunes

431 Do sítio arqueológico ao museu: um percurso (também) didático Lídia Fernandes

447 Estão todos convidados para a Festa! E para dançar também... O projecto do Serviço Educativo do Museu Arqueológico do Carmo na $5^{\underline{a}}$ Edição da Festa da Arqueologia Rita Pires dos Santos

459 O “Clã de Carenque”, um projeto didático de arqueologia Eduardo Gonzalez Rocha

469 Mediação cultural: peixe que puxa carroça nas Ruínas Romanas de Troia Inês Vaz Pinto / Ana Patrícia Magalhães / Patrícia Brum / Filipa Santos

481 Didática Arqueológica, experiências do Projeto Mértola Vila Museu Maria de Fátima Palma / Clara Rodrigues / Susana Gómez / Lígia Rafael

\section{Arte Rupestre}

497 Os inventários de arte rupestre em Portugal Mila Simões de Abreu

513 O projeto FIRST-ART - conservação, documentação e gestão das primeiras manifestações de arte rupestre no Sudoeste da Península Ibérica: as grutas do Escoural e Maltravieso Sara Garcês / Hipólito Collado / José Julio García Arranz / Luiz Oosterbeek / António Carlos Silva / Pierluigi Rosina / Hugo Gomes / Anabela Borralheiro Pereira / George Nash / Esmeralda Gomes / Nelson Almeida / Carlos Carpetudo

523 Trabalhos de documentação de arte paleolítica realizados no âmbito do projeto PalæoCôa André Tomás Santos / António Fernando Barbosa / Luís Luís / Marcelo Silvestre / Thierry Aubry

537 Imagens fantasmagóricas, silhuetas elusivas: as figuras humanas na arte do Paleolítico Superior da região do Côa Mário Reis

$55^{1}$ Os motivos zoomórficos representados nas placas de tear de Vila Nova de São Pedro (Azambuja, Portugal) Andrea Martins / César Neves / José M. Arnaud / Mariana Diniz

571 Arte Rupestre do Monte de Góios (Lanhelas, Caminha). Síntese dos resultados dos trabalhos efectuados em 2007-2009 Mário Varela Gomes

599 Gravuras rupestres de barquiformes no Monte de S. Romão, Guimarães, Noroeste de Portugal Daniela Cardoso

613 Círculos segmentados gravados na Bacia do Rio Lima (Noroeste de Portugal): contributos para o seu estudo Diogo Marinho / Ana M.S. Bettencourt / Hugo Aluai Sampaio

631 Equídeos gravados no curso inferior do Rio Mouro, Monção (NW Portugal). Análise preliminar Coutinho, L.M. / Bettencourt, A.M.S / Sampaio, Hugo A.S

645 Paletas na Arte Rupestre do Noroeste de Portugal. Inventário preliminar Bruna Sousa Afonso / Ana M. S. Bettencourt / Hugo A. Sampaio 


\section{Pré-História}

661 O projeto Miño/Minho: balanço de quatro anos de trabalhos arqueológicos Sérgio Monteiro-Rodrigues / João Pedro Cunha-Ribeiro / Eduardo Méndez-Quintas / Carlos Ferreira / Pedro Xavier / José Meireles / Alberto Gomes / Manuel Santonja / Alfredo Pérez-González

677 A ocupação paleolítica da margem esquerda do Baixo Minho: a indústria lítica do sítio de Pedreiras 2 (Monção, Portugal) e a sua integração no contexto regional Carlos Ferreira / João Pedro Cunha-Ribeiro / Sérgio Monteiro-Rodrigues / Eduardo Méndez-Quintas / Pedro Xavier / José Meireles / Alberto Gomes / Manuel Santonja / Alfredo Pérez-González

693 O sítio acheulense do Plistocénico médio da Gruta da Aroeira Joan Daura / Montserrat Sanz / Filipa Rodrigues / Pedro Souto / João Zilhão

703 As sociedades neandertais no Barlavento algarvio: modelos preditivos com recurso aos SIG

Daniela Maio

715 A utilização de quartzo durante o Paleolítico Superior no território dos vales dos rios Vouga e Côa

Cristina Gameiro / Thierry Aubry / Bárbara Costa / Sérgio Gomes / Luís Luís / Carmen Manzano / André Tomás Santos

733 Uma perspetiva diacrónica da ocupação do concheiro do Cabeço da Amoreira (Muge, Portugal) a partir da tecnologia lítica Joana Belmiro / João Cascalheira / Célia Gonçalves

745 Novos dados sobre a Pré-história Antiga no concelho de Palmela. A intervenção arqueológica no sítio do Poceirão I

Michelle Teixeira Santos

757 Problemas em torno de Datas Absolutas Pré-Históricas no Norte do Alentejo Jorge de Oliveira

771 Povoamento pré-histórico nas áreas montanhosas do NO de Portugal: o Abrigo 1 de Vale de Cerdeira Pedro Xavier / José Meireles / Carlos Alves

783 Apreciação do povoamento do Neolítico Inicial na Baixa Bacia do Douro. A Lavra I (Serra da Aboboreira) como caso de estudo Maria de Jesus Sanches

797 O Processo de Neolitização na Plataforma do Mondego: os dados do Sector C do Outeiro dos Castelos de Beijós (Carregal do Sal)

João Carlos de Senna-Martinez / José Manuel Quintã Ventura / Andreia Carvalho / Cíntia Maurício

823 Novos trabalhos na Lapa da Bugalheira (Almonda, Torres Novas) Filipa Rodrigues / Pedro Souto / Artur Ferreira / Alexandre Varanda / Luís Gomes / Helena Gomes / João Zilhão

837 A pedra polida e afeiçoada do sítio do Neolítico médio da Moita do Ourives (Benavente, Portugal)

César Neves

857 Casal do Outeiro (Encarnação, Mafra): novos contributos para o conhecimento do povoamento do Neolítico final na Península de Lisboa.

Cátia Delicado / Carlos Maneira e Costa / Marta Miranda / Ana Catarina Sousa

873 Stresse infantil, morbilidade e mortalidade no sítio arqueológico do Neolítico Final/ Calcolítico ( $4^{\circ}$ e $3^{\circ}$ milénio a.C.) do Monte do Carrascal 2 (Ferreira do Alentejo, Beja) Liliana Matias de Carvalho / Sofia N. Wasterlain 
885 Come together: O Conjunto Megalítico das Motas (Monção, Viana do Castelo) e as expressões Campaniformes do Alto Minho Ana Catarina Basílio / Rui Ramos

899 Trabalhos arqueológicos no sítio Calcolítico da Pedreira do Poio Carla Magalhães / João Muralha / Mário Reis / António Batarda Fernandes

913 O sítio arqueológico de Castanheiro do Vento. Da arquitectura do sítio à arquitectura de um território João Muralha Cardoso

925 Estudo zooarqueológico das faunas do Calcolítico final de Vila Nova de São Pedro (Azambuja, Portugal): Campanhas de 2017 e 2018 Cleia Detry / Ana Catarina Francisco / Mariana Diniz / Andrea Martins / César Neves / José Morais Arnaud

943 As faunas depositadas no Museu Arqueológico do Carmo provenientes de Vila Nova de São Pedro (Azambuja): as campanhas de 1937 a 1967 Ana Catarina Francisco / Cleia Detry / César Neves / Andrea Martins / Mariana Diniz / José Morais Arnaud

959 Análise funcional de material lítico em sílex do castro de Vila Nova de S. Pedro (Azambuja, Portugal): uma primeira abordagem Rafael Lima

971 O recinto da Folha do Ouro 1 (Serpa) no contexto dos recintos de fossos calcolíticos alentejanos

António Carlos Valera / Tiago do Pereiro / Pedro Valério / António M. Monge Soares

\section{Proto-História}

987 Produção de sal marinho na Idade do Bronze do noroeste Português. Alguns dados para uma reflexão

Ana M. S. Bettencourt / Sara Luz / Nuno Oliveira / Pedro P. Simões / Maria Isabel C. Alves / Emílio Abad-Vidal

1001 A estátua-menir do Pedrão ou de São Bartolomeu do Mar (Esposende, noroeste de Portugal) no contexto arqueológico da fachada costeira de entre os rios Neiva e Cávado Ana M. S. Bettencourt / Manuel Santos-Estévez / Pedro Pimenta Simões / Luís Gonçalves

1015 O Castro do Muro (Vandoma/Baltar, Paredes) - notas para uma biografia de ocupação da Idade do Bronze à Idade Média

Maria Antónia D. Silva / Ana M. S. Bettencourt / António Manuel S. P. Silva / Natália Félix

1031 Do Bronze Final à Idade Média - continuidades e hiatos na ocupação de Povoados em Oliveira de Azeméis João Tiago Tavares / Adriaan de Man

1041 As faunas do final da Idade do Bronze no Sul de Portugal: leituras desde o Outeiro do Circo (Beja)

Nelson J. Almeida / Íris Dias / Cleia Detry / Eduardo Porfírio / Miguel Serra

1055 A Espada do Monte das Oliveiras (Serpa) - uma arma do Bronze Pleno do Sudoeste Rui M. G. Monge Soares / Pedro Valério / Mariana Nabais / António M. Monge Soares

1065 São Julião da Branca (Albergaria-a-Velha) - Investigação e valorização de um povoado do Bronze Final

António Manuel S. P. Silva / Paulo A. P. Lemos / Sara Almeida e Silva / Edite Martins de Sá

1083 Do castro de S. João ao Mosteiro de Santa Clara: notícia de uma intervenção arqueológica, em Vila do Conde Rui Pinheiro 
1095 O castro de Ovil (Espinho), um quarto de século de investigação - resultados e questões em aberto

Jorge Fernando Salvador / António Manuel S. P. Silva

1111 O Castro de Salreu (Estarreja), um povoado proto-histórico no litoral do Entre Douro e Vouga

Sara Almeida e Silva / António Manuel S. P. Silva / Paulo A. P. Lemos / Edite Martins de Sá

1127 Castro de Nossa Senhora das Necessidades (Sernancelhe): uma primeira análise artefactual Telma Susana O. Ribeiro

${ }_{1141}$ A cividade de Bagunte. O estado atual da investigação Pedro Brochado de Almeida

1153 Zoomorfos na cerâmica da Idade do Ferro no NW Peninsular: inventário, cronologias e significado Nuno Oliveira / Cristina Seoane

1163 Vasos gregos em Portugal: diferentes maneiras de contar a história do intercâmbio cultural na Idade do Ferro

Daniela Ferreira

1175 Os exotica da necrópole da Idade do Ferro do Olival do Senhor dos Mártires (Alcácer do Sal) no seu contexto regional

Francisco B. Gomes

\section{Antiguidade Clássica e Tardia}

1191 O uso de madeira como combustível no sítio da Quinta de Crestelos (Baixo Sabor): da Idade do Ferro à Romanização Filipe Vaz / João Tereso / Sérgio Simões Pereira / José Sastre / Javier Larrazabal Galarza / Susana Cosme / José António Pereira / Israel Espi

1207 Cultivos de Época Romana no Baixo Sabor: continuidade em tempos de mudança? João Pedro Tereso / Sérgio Simões Pereira / Filipe Santos / Luís Seabra / Filipe Vaz

1221 A casa romana na Hispânia: aplicação dos modelos itálicos nas províncias ibéricas Fernanda Magalhães / Diego Machado / Manuela Martins

1235 As pinturas murais romanas da Rua General Sousa Machado, n. ${ }^{5}$ 1, Chaves José Carvalho

1243 Trás do Castelo (Vale de Mir, Pegarinhos, Alijó) - Uma exploração agrícola romana do Douro

Tony Silvino / Pedro Pereira

1255 A sequência de ocupação no quadrante sudeste de Bracara Augusta: as transformações de uma unidade doméstica Lara Fernandes / Manuela Martins

1263 Os Mosaicos com decoração geométrica e geométrico-vegetalista dos sítios arqueológicos da área do Conuentus Bracaraugustanus. Novas abordagens quanto à conservação, restauro, decoração e datação Maria de Fátima Abraços / Licínia Wrench

1277 “Casa Romana” do Castro de São Domingos (Cristelos, Lousada): Escavação, Estudo e Musealização Paulo André de P. Lemos

1291 A arqueobotânica no Castro de Guifões (Matosinhos, Noroeste de Portugal): O primeiro estudo carpológico

Luís Seabra / Andreia Arezes / Catarina Magalhães / José Varela / João Pedro Tereso 
1305 Um Horreum Augustano na Foz do Douro (Monte do Castelo de Gaia, Vila Nova de Gaia) Rui Ramos

1311 Ponderais romanos na Lusitânia: padrões, formas, materiais e contextos de utilização Diego Barrios Rodríguez

1323 Um almofariz centro-itálico na foz do Mondego

Marco Penajoia

1335 Estruturas romanas de Carnide - Lisboa Luísa Batalha / Mário Monteiro / Guilherme Cardoso

1347 O contexto funerário do sector da "necrópole NO" da Rua das Portas de S. Antão (Lisboa): o espaço, os artefactos, os indivíduos e a sua interconectividade na interpretação do passado Sílvia Loja, José Carlos Quaresma, Nelson Cabaço, Marina Lourenço, Sílvia Casimiro, Rodrigo Banha da Silva, Francisca Alves-Cardoso

${ }_{1361}$ Povoamento em época Romana na Amadora - resultados de um projeto pluridisciplinar Gisela Encarnação / Vanessa Dias

1371 A Arquitectura Residencial em Mirobriga (Santiago do Cacém): contributo a partir de um estudo de caso Filipe Sousa / Catarina Felício

${ }_{1385}$ O fim do ciclo. Saneamento e gestão de resíduos nos edifícios termais de Mirobriga (Santiago do Cacém)

Catarina Felício / Filipe Sousa

1399 Balsa, Topografia e Urbanismo de uma Cidade Portuária Vítor Silva Dias / João Pedro Bernardes / Celso Candeias / Cristina Tété Garcia

1413 No Largo das Mouras Velhas em Faro (2017): novas evidências da necrópole norte de Ossonoba e da sua ocupação medieval Ricardo Costeira da Silva / Paulo Botelho / Fernando Santos / Liliana Nunes

1429 Instrumentos de pesca recuperados numa fábrica de salga em Ossonoba (Faro) Inês Rasteiro / Ricardo Costeira da Silva / Paulo Botelho

1439 A Necrópole Romana do Eirô, Duas Igrejas (Penafiel): intervenção arqueológica de 2016 Laura Sousa / Teresa Soeiro

1457 Ritual, descarte ou afetividade? A presença de Canis lupus familiaris na Necrópole Noroeste de Olisipo (Lisboa)

Beatriz Calapez Santos / Sofia Simões Pereira / Rodrigo Banha da Silva / Sílvia Casimiro / Cleia Detry / Francisca Alves Cardoso

1467 Dinâmicas económicas em Bracara na Antiguidade Tardia Diego Machado / Manuela Martins / Fernanda Magalhães / Natália Botica

1479 Cerâmicas e Vidros da Antiguidade Tardia do Edifício sob a Igreja do Bom Jesus (Vila Nova de Gaia) Joaquim Filipe Ramos

1493 Novos contributos para a topografia histórica de Mértola no período romano e na Antiguidade Tardia Virgílio Lopes

\section{8. Época Medieval}

1511 Cerâmicas islâmicas no Garb setentrional "português": algumas evidências e incógnitas Constança dos Santos / Helena Catarino / Susana Gómez / Maria José Gonçalves / Isabel Inácio / Gonçalo Lopes / Jacinta Bugalhão / Sandra Cavaco / Jaquelina Covaneiro / Isabel Cristina Fernandes / Ana Sofia Gomes 
1525 Contributo para o conhecimento da cosmética islâmica, em Silves, durante a Idade Média Rosa Varela Gomes

1537 Yábura e o seu território - uma análise histórico-arqueológica de Évora entre os séculos VIII-XII José Rui Santos

1547 A encosta sul do Castelo de Palmela - resultados preliminares da escavação arqueológica Luís Filipe Pereira / Michelle Teixeira Santos

1559 A igreja de São Lourenço (Mouraria, Lisboa): um conjunto de silos e de cerâmica medieval islâmica

Andreia Filipa Moreira Rodrigues

1571 O registo material de movimentações populacionais no Médio Tejo, durante os séculos XII-XIII. Dois casos de "sunken featured buildings", nos concelhos de Cartaxo e Torres Novas Marco Liberato / Helena Santos / Nuno Santos

1585 O nordeste transmontano nos alvores da Idade média. Notas para reflexão Ana Maria da Costa Oliveira

1601 Sepulturas escavadas na rocha do Norte de Portugal e do Vale do Douro: primeiros resultados do Projecto SER-NPVD

Mário Jorge Barroca / César Guedes / Andreia Arezes / Ana Maria Oliveira

1619 "Portucalem Castrum Novum" entre o Mediterrâneo e o Atlântico: o estudo dos materiais cerâmicos alto-medievais do arqueossítio da rua de D. Hugo, nํ. 5 (Porto) João Luís Veloso

1627 A Alta Idade Média na fronteira de Lafões: notas preliminares sobre a Arqueologia no Concelho de Vouzela

Manuel Luís Real / Catarina Tente

1641 Um conjunto cerâmico medieval fora de portas: um breve testemunho aveirense Susana Temudo

${ }_{1651}$ Os Lóios do Porto: uma perspetiva integrada no panorama funerário da Baixa Idade Média à Época Moderna em meios urbanos em Portugal

Ana Lema Seabra

1659 O Caminho Português Interior de Santiago como eixo viário na Idade Média Pedro Azevedo

1665 Morfologia Urbana: Um exercício em torno do Castelo de Ourém André Donas-Botto / Jaqueline Pereira

1677 Intervenção arqueológica na Rua Marquês de Pombal/Largo do Espírito Santo (Bucelas, Loures)

Florbela Estêvão / Nathalie Antunes-Ferreira / Dário Ramos Neves / Inês Lisboa

1691 O Cemitério Medieval do Poço do Borratém e a espacialidade funerária na cidade de Lisboa Inês Belém / Vanessa Filipe / Vasco Noronha Vieira / Sónia Ferro / Rodrigo Banha da Silva

1705 Um Espaço Funerário Conventual do séc. XV em Lisboa: o caso do Convento de São Domingos da Cidade Sérgio Pedroso / Sílvia Casimiro / Rodrigo Banha da Silva / Francisca Alves Cardoso

\section{9. Época Moderna e Contemporânea}

1721 Arqueologia Moderna em Portugal: algumas reflexões críticas em torno da quantificação de conjuntos cerâmicos e suas inferências históricas e antropológicas Rodrigo Banha da Silva / André Bargão / Sara da Cruz Ferreira

1733 Faianças de dois contextos entre os finais do século XVI e XVIII do Palácio dos Condes de Penafiel, Lisboa

Martim Lopes / Tomás Mesquita 
1747 Um perfil de consumo do século XVIII na foz do Tejo: O caso do Mercado da Ribeira, Lisboa Sara da Cruz Ferreira / Rodrigo Banha da Silva / André Bargão

1761 Os Cachimbos dos Séculos XVII e XVIII do Palácio Mesquitela e Convento dos Inglesinhos (Lisboa)

Inês Simão / Marina Pinto / João Pimenta / Sara da Cruz Ferreira / André Bargão / Rodrigo Banha da Silva

1775 "Tomar os fumos da erua que chamão em Portugal erua sancta». Estudo de Cachimbos provenientes da Rua do Terreiro do Trigo, Lisboa

Miguel Martins de Sousa / José Pedro Henriques / Vanessa Galiza Filipe

1787 Cachimbos de Barro Caulínitico da Sé da Cidade Velha (República de Cabo Verde)

Rodrigo Banha da Silva / João Pimenta / Clementino Amaro

1801 Algumas considerações sobre espólio não cerâmico recuperado no Largo de Jesus (Lisboa) Carlos Boavida

1815 Adereços de vidro, dos séculos XVI-XVIII, procedentes do antigo Convento de Santana de Lisboa (anéis, braceletes e contas)

Joana Gonçalves / Rosa Varela Gomes / Mário Varela Gomes

1837 Da ostentação, luxo e poder à simplicidade do uso quotidiano: arqueologia e simbologia de joias e adornos da Idade Moderna Portuguesa Jéssica Iglésias

1849 Os amuletos em Portugal - dos objetos às superstições: o coral vermelho Alexandra Vieira

1865 Cerâmicas de Vila Franca de Xira nos séculos XV e XVI Eva Pires

1879 «Não passa por teu o que me pertence». Marcas de individualização associadas a faianças do Convento de Nossa Senhora de Aracoeli, Alcácer do Sal Catarina Parreira / Íris Fragoso / Miguel Martins de Sousa

1891 Cerâmica de Leiria: alguns focos de produção

Jaqueline Pereira / André Donas-Botto

1901 Os Fornos na Rua da Biquinha, em Óbidos Hugo Silva / Filipe Oliveira

1909 A casa de Pêro Fernandes, contador dos contos de D. Manuel I: o sítio arqueológico da Silha do Alferes, Seixal (século XVI) Mariana Nunes Ferreira

1921 O Alto da Vigia (Sintra) e a vigilância e defesa da costa Alexandre Gonçalves / Sandra Santos

1937 O contexto da torre sineira da Igreja de Santa Maria de Loures Paulo Calaveira / Martim Lopes

1949 A Necrópole do Hospital Militar do Castelo de São Jorge e as práticas funerárias na Lisboa de Época Moderna Susana Henriques / Liliana Matias de Carvalho / Ana Amarante / Sofia N. Wasterlain

1963 SAND - Sarilhos Grandes Entre dois Mundos: o adro da Igreja e a Paleobiologia dos ossos humanos recuperados

Paula Alves Pereira / Roger Lee Jesus / Bruno M. Magalhães

1975 Expansão urbana da vila de Cascais no século XVII e XVIII: a intervenção arqueológica na Rua da Vitória no 15 a 17

Tiago Pereira / Vanessa Filipe

1987 Novos dados para o conhecimento do Urbanismo de Faro em época Moderna Ana Rosa 
1995 Um exemplo de Arqueologia Urbana em Alcoutim: o Antigo Edifício dos CTT Marco Fernandes / Marta Dias / Alexandra Gradim / Virgílio Lopes / Susana Gómez Martínez

2007 Palácio dos Ferrazes (Rua das Flores/Rua da Vitória, Porto): a cocheira de Domingos Oliveira Maia

Francisco Raimundo

2021 As muitas vidas de um edifício urbano: História, Arqueologia e Antropologia no antigo Recreatório Paroquial de Penafiel Helena Bernardo / Jorge Sampaio / Marta Borges

2035 O convento de Nossa Senhora da Esperança de Ponta Delgada: o contributo da arqueologia para o conhecimento de um monumento identitário João Gonçalves Araújo / N’Zinga Oliveira

2047 Arqueologia na ilha do Corvo... em busca da capela de Nossa Senhora do Rosário Tânia Manuel Casimiro / José Luís Neto / Luís Borges / Pedro Parreira

2059 Perdidos à vista da Costa. Trabalhos arqueológicos subaquáticos na Barra do Tejo Jorge Freire / José Bettencourt / Augusto Salgado

2071 Arqueologia marítima em Cabo Verde: enquadramento e primeiros resultados do projecto CONCHA

José Bettencourt / Adilson Dias / Carlos Lima / Christelle Chouzenoux / Cristóvão Fonseca / Dúnia Pereira / Gonçalo Lopes / Inês Coelho / Jaylson Monteiro / José Lima / Maria Eugénia Alves / Patrícia Carvalho / Tiago Silva

2085 Trabalhos arqueológicos na Cidade Velha (Ribeira Grande de Santiago, Cabo Verde): reflexões sobre um projecto de investigação e divulgação patrimonial André Teixeira / Jaylson Monteiro / Mariana Mateus / Nireide Tavares / Cristovão Fonseca / Gonçalo C. Lopes / Joana Bento Torres / Dúnia Pereira / André Bargão / Aurélie Mayer / Bruno Zélie / Carlos Lima / Christelle Chouzenoux / Inês Henriques / Inês Pinto Coelho / José Lima / Patrícia Carvalho / Tiago Silva

2103 A antiga fortificação de Quelba / Khor Kalba (E.A.U.). Resultados de quatro campanhas de escavações, problemáticas e perspectivas futuras Rui Carita / Rosa Varela Gomes / Mário Varela Gomes / Kamyar Kamyad

2123 Colónias para homens novos: arqueologia da colonização agrária fascista no noroeste ibérico Xurxo Ayán Vila / José Mạ . Señorán Martín 


\title{
UM EXEMPLO DE ARQUEOLOGIA URBANA EM ALCOUTIM: O ANTIGO EDIFÍ́CIO DOS CTT
}

\author{
Marco Fernandes ${ }^{1}$, Marta Dias ${ }^{2}$, Alexandra Gradim ${ }^{3}$, Virgílio Lopes ${ }^{4}$, Susana Gómez Martínez ${ }^{5}$
}

\begin{abstract}
RESUMO
Este artigo pretende divulgar os principais resultados dos trabalhos arqueológicos desenvolvidos, entre Agosto de 2019 e Fevereiro de 2020, pela equipa do Campo Arqueológico de Mértola, num edifício conhecido como os Antigos CTT. Este imóvel localizava-se a Oeste do castelo de Alcoutim e dentro do seu perímetro amuralhado de período moderno, sendo, desde logo, uma área de carácter arqueológico importante para a compreensão da dinâmica ocupacional deste aglomerado.

Esta intervenção decorreu em duas fases distintas: sondagens de diagnóstico eacompanhamento arqueológico / escavação. Tais acções permitiram a identificação de um conjunto de estruturas e de níveis associados que apontam para uma diacronia que se inicia no século XV.
\end{abstract}

Palavras-chave: Alcoutim, Arqueologia Urbana, Idade Moderna e Contemporânea.

\section{ABSTRACT}

The aim of the present article is to divulge the main results of the archaeological works developed by the Campo Arqueológico de Mértola team in a building known as the Antigos CTT, between August 2019 and February 2020. This property is located to the west of Alcoutim Castle and inside its $17^{\text {th }}$ century walls, being an important archaeological site to understand the occupational dynamic of this urban area.

This intervention was performed in two distinct phases: diagnostic survey and archaeological monitoring / excavation. These interventions led to the identification of an associated group of structures and layers that point to a diachrony beginning in the $15^{\text {th }}$ century.

Keywords: Alcoutim, Urban Archaeology, Modern and Contemporary Age.

\section{INTRODUÇÃO ${ }^{6}$}

Os trabalhos arqueológicos realizados no Antigo Edifício dos CTT de Alcoutim, no âmbito do projecto de construção, neste local, de um novo edifício de habitação colectiva, numa área total de $305 \mathrm{~m}^{2}$, promovido pela Câmara Municipal de Alcoutim, foram realizados pelo Campo Arqueológico de Mértola e decorreram entre Agosto de 2019 e Fevereiro de 2020 (Figura 1).

\footnotetext{
1. CEAACP - Centro de Estudos de Arqueologia, Artes e Ciências do Património / CAM - Campo Arqueológico de Mértola; marcodiasf@gmail.com

2. CAM - Campo Arqueológico de Mértola; mrtdiax@gmail.com

3. Câmara Municipal de Alcoutim; arqueologia@cm-alcoutim.pt

4. CEAACP - Centro de Estudos de Arqueologia, Artes e Ciências do Património / CAM - Campo Arqueológico de Mértola / Bolseiro Pós-doutoramento da FCT - Fundação para a Ciência e Tecnologia; virgilioamlopes@sapo.pt
}

5. Departamento de História da Universidade de Évora / CEAACP - Centro de Estudos de Arqueologia, Artes e Ciências do Património / CAM - Campo Arqueológico de Mértola; susanagomez@sapo.pt

6. Este artigo segue o antigo acordo ortográfico. 


\section{ENQUADRAMENTO GEOGRÁFICO E HISTÓRICO}

O imóvel localizava-se na Rua D. Sancho II, nº 3, em Alcoutim, sede de Concelho, na União de freguesias de Alcoutim e do Pereiro, na zona Nordeste da Região do Algarve, pertencente ao Distrito de Faro.

Esta localidade implanta-se na margem direita do Rio Guadiana, defronte da povoação espanhola de Sanlúcar de Guadiana, numa pequena península orientada a Norte, fechada no lado Noroeste pela Ribeira dos Cadavais ou de S. Marcos (Nunes, 1985, pp. 21 e 46), afluente do Guadiana, onde, em termos geológicos, predominam os xistos e grauvaques.

O território de Alcoutim tem uma ocupação humana atestada desde o Paleolítico Médio, notando-se um incremento a partir do Calcolítico, com a fixação de vários núcleos habitacionais ao longo deste espaço territorial (Gradim, 2006, p. 20), ligados à exploração dos recursos metalíferos, relacionados com a Faixa Piritosa Ibérica que se estende por toda esta região.

No local da actual vila foram identificados, de forma residual, durante os trabalhos arqueológicos no castelo, dos anos 9o do século XX, estruturas e materiais enquadrados na Idade do Ferro e época romano-republicana (Catarino, 2003, p. 163; 1994, p. 666). Durante o período romano deverá ter existido uma ocupação humana, na zona do Rossio, uma vez que, durante a construção de um tanque de tratamento de esgotos se identificaram materiais de construção deste período, dos quais "se destacam alguns tijolos de quadrante» (Catarino, 1994, p. 666). Durante a Antiguidade Tardia e o período islâmico não existem elementos identificados que permitam supor a existência de uma comunidade residente neste local, exceptuando o sítio do Castelo Velho de Alcoutim, a cerca de $1 \mathrm{~km}$ a Norte, cujas escavações dirigidas por Helena Catarino permitiram auferir que a sua fundação se dá em finais do século VIII, ou já no século IX, durante o período omíada, recebendo uma restruturação durante o século $\mathrm{X}$, em período califal (Catarino, 1997/1998, pp. 586-587), e, finalmente, sendo abandonado no final do período das taifas (Catarino, 1997/1998, p. 598).

No final da década de trinta do século XIII o território de Alcoutim entra, de modo definitivo, na esfera do controlo cristão, e em 1302 D. Dinis atribui o padroado das igrejas e do termo de Alcoutim à Ordem de Santiago (Magalhães, 2008, p. 52). A 9 de janeiro de 1304, o mesmo monarca concede carta de foral, instituindo "que esta zona fosse povoada por homiziados, criminosos civis", dando-se a construção do castelo de Alcoutim, que funcionará como praça militar fronteiriça (Catarino, 1994, p. 659).

No governo de D. Fernando são assinadas as Pazes de Alcoutim (1371), entre este monarca e D. Henrique II de Castela (Catarino, 1994, p. 659). É provável que, neste momento, tenha sido construída a barbacã do castelo (Gradim, 2006, p. 36), identificável no desenho do Livro das Fortalezas de Duarte d'Armas, de 1509-1510, em avançado estado de ruína (Almeida, 1943, pp. 25 e 27) (Figura 2).

Nos finais do século XV, por iniciativa de D. Manuel, é criado o Condado de Alcoutim (Gradim, 2008, pp. 40-41), que, mais tarde, será integrado na Casa do Infantado, na segunda metade do século XVII, até à sua extinção em 1834 (Nunes, 1985, pp. 165-166). Durante as Guerras da Restauração (1640-1668), "face à necessidade de reforçar o sistema defensivo desta vila fronteiriça, assiste-se à construção das muralhas e das suas três portas. Pensamos que a cerca moderna poderá ter sido edificada na década de sessenta, [do século XVII,] durante o reinado de D. Afonso VI (...). Facto surpreendente na muralha seiscentista é a sua longa extensão em taipa. Esta debilidade construtiva da frente terrestre pressupõe uma urgência na edificação que se sobrepõe à resistência e eficácia do aparelho, só verificada do lado da via fluvial onde o aparelho era de alvenaria de pedra" (Gradim, 2006, pp. 40-41).

Em 1855 dá-se a instalação do telégrafo em Portugal e pouco tempo depois este serviço chega a Alcoutim. O edifício, no qual se realizaram estes trabalhos arqueológicos, terá sido, pelo menos, a partir de 1880, a sede da estação de telégrafo - postal, conforme era designada, sendo que o serviço postal já existia desde 1853 , aquando da primeira reforma postal (Borralho, 2015, pp. 3-17), assim como a residência dos guarda-fios, profissão que tinha como função a manutenção da linha telegráfica na área da sua circunscrição. No século XX o edifício foi adaptado a posto dos CTT, perdendo o seu carácter residencial só nos anos 9o, mantendo-se esta utilização até 2002.

\section{TRABALHOS REALIZADOS}

Os trabalhos arqueológicos realizaram-se entre 20 de Agosto de 2019 a 7 de Fevereiro de 2020 e desenvolveram-se em dois momentos distintos. Na pri- 
meira fase, pré-empreitada, realizaram-se quatro sondagens de diagnóstico, duas no logradouro do imóvel, uma no compartimento 7 (cozinha) e outra na sala de atendimento / recepção (compartimento 1), num total de $26 \mathrm{~m}^{2}$ (Figura 3). No segundo momento, com o arranque dos trabalhos da empreita$\mathrm{da}$, realizou-se o acompanhamento arqueológico da demolição do edifício pré-existente, assim como da escavação mecânica dos depósitos até ao final do período moderno. A partir dos níveis deste período fez-se uma escavação arqueológica manual, até ao substrato rochoso. As únicas zonas que não foram contempladas com escavação integral dos níveis de formação antrópicos tratam-se da área $\mathrm{A}$, pela cota de afectação estar estabelecida nos $26,85 \mathrm{~m}$, e a área $\mathrm{B}$, por não estar prevista qualquer construção ali, dentro deste empreendimento.

\section{SÍNTESE EVOLUTIVA DO ESPAÇO}

Dado que o edifício dos Antigos CTT de Alcoutim está localizado em meio urbano, muito próximo do castelo, projectou-se que este trabalho poderia responder quando e de que forma se teria dado a evolução do aglomerado nesta zona da vila.

De facto, este revelou ser um espaço vivo e dinâmico durante seis séculos, onde, de forma gradual, se foi construindo, usando e umas vezes abandonando, outras refuncionalizando.

Devido a este emaranhado de elementos recuperados, foi necessário destrinçar que estruturas e contextos pertenciam a cada momento, de modo a se recuperar uma leitura fundamentada da dinâmica de ocupação humana daquele espaço. Através da informação estratigráfica recolhida, foram identificados seis momentos diferentes (Figura 4).

\subsection{Fase I (século XV)}

O momento mais antigo identificado e atribuído, de forma genérica, ao século $\mathrm{XV}$, está associado à edificação de um ambiente, do qual apenas restou pouco mais do que $0,5 \mathrm{~m}$ de altura do seu aparelho construtivo, e vestígios associados do antigo arruamento da Rua das Portas de Tavira (Gradim, 2006, p. 47), actual Rua D. Sancho II, na metade Norte do compartimento I (Figura 3). Deste modo, é possível fazer recuar a existência de construções, neste lado do antigo arruamento, ainda nesta fase (Gradim, 2006, p. 66).

\subsection{Fase II (século XVI)}

Na segunda fase ocupacional dá-se a construção de um muro de contenção de talude (área C - Figuras. 3 e 4) e de duas novas vivendas. A primeira destas unidades habitacionais era constituída, pelo menos, por três compartimentos. Dela apenas se identificou, dentro da área de intervenção, uma das suas divisões (Área E - Figuras. 3, 4, 5 e 6), mas depreendeu-se a existência dos outros dois ambientes pela ocorrência de vãos de acesso, na direção das parcelas vizinhas a Noroeste e a Nordeste. Este conjunto integrava um sistema de drenagem de águas pluviais. A segunda moradia, localizada entre a metade Norte do compartimento 1 e os compartimentos 2 e 3 (Figuras. 3, 4 e 6), era composta por duas divisões, tendo a casa de entrada um nível de circulação em calçada de seixos rolados.

\subsection{Fase III (século XVII)}

Ao terceiro momento estão associadas quatro fossas de despejo de resíduos, identificadas entre a metade Sul do compartimento 1 e compartimento 6 (Figura 3 e 6), resultantes da actividade de uma forja situada nas proximidades, mas não identificada dentro da área deste empreendimento.

$\mathrm{Na}$ área $\mathrm{B}$ construiu-se um primeiro ambiente, possivelmente, de carácter habitacional, enquanto que na área A surgem dois alinhamentos, que também indicam tratarem-se de uma construção com as mesmas características (Figuras 3 e 4).

Em relação à segunda habitação (Figura 4 e 6), acima referida para a fase II, dá-se a desactivação do nível de circulação original da casa de entrada, em calçada de seixos rolados, que será cortado por um novo sistema de drenagem de águas pluviais, e em cima do qual será colocado um novo pavimento de tijoleira. $\mathrm{Na}$ casa de dentro desta unidade habitacional é construído um pavimento de calçada de pedra de xisto durante esta fase.

\subsection{Fase IV (século XVIII)}

No quarto momento sucede-se o abandono do ambiente da área E (Figuras 3, 4, 5 e 6), referido na fase II, dando-se o entaipamento dos vãos de acesso que com ele comunicavam, assim como o preenchimento deste espaço com um nível de aterro.

$\mathrm{Na}$ área $\mathrm{D}$ constrói-se um novo muro de contenção de talude, identificado, inicialmente, durante os trabalhos da sondagem 2 (Figuras 3 e 4).

$\mathrm{Na}$ área $\mathrm{B}$ ocorre a construção de um novo comparti- 
mento, cujos embasamentos eram constituídos por alvenaria de xisto ligada com terra, desenvolvendo-se a construção em altura dos mesmos em taipa (Figuras 3 e 4).

$\mathrm{Na}$ área A erguem-se dois alinhamentos, um deles limítrofe com o Largo do Castelo, que atestam a existência de uma nova unidade habitacional confinante com este arruamento (Figuras 3 e 4 ).

$\mathrm{Na}$ segunda habitação referida para a fase II, localizada entre a metade Norte do compartimento 1 e os compartimentos 2 e 3 (Figuras 3, 4 e 6), procede-se ao entaipamento do vão de acesso que ligava os dois ambientes desta unidade. Para tal é construído um novo pequeno compartimento no seu canto Norte, possível despensa, desactivando-se, para tal, o conjunto de degraus que estabeleciam a ligação com o vão de acesso atrás referido.

Na metade Sul do compartimento 1 é construído um novo caneiro de drenagem de águas pluviais, que se articularia com um outro, identificado no compartimento 7 (Figuras 3, 4 e 6). Ainda neste último espaço, dá-se a construção de duas estruturas positivas que indiciam a existência de um novo ambiente, de carácter habitacional.

É também, neste momento, que são construídos os primeiros alinhamentos em alvenaria de pedra do compartimento 9 (Figuras 3 e 4 ), formando um conjunto de dois espaços desnivelados entre si. No ambiente do patamar inferior, dá-se a construção de um poial e de um sistema de drenagem de águas pluviais.

4.5. Fase V (finais do século XVIII - inícios do século XIX)

No quinto momento, o ambiente interior do conjunto habitacional, referido na zona da metade Norte do compartimento 1 e compartimentos 2 e 3 , é desfuncionalizado durante a fase IV e começa a servir como vazadouro de lixo doméstico. Já a casa de entrada desta unidade habitacional é abandonada e o seu espaço preenchido com entulhos produzidos pela sua demolição, após a construção de uma nova parede exterior, na Rua D. Sancho II. Com a regularização do topo deste nível de entulho, dá-se a construção de uma nova divisão, cujo nível de pavimento era composto por argamassa, que articulava com um ambiente que terá existido, e do qual não se identificaram vestígios, no lado da metade Sul do compartimento 1 e compartimento 6 (Figuras 3,4 e 6).
4.6. Fase VI (Segunda metade do século XIX inícios do século XXI)

Será no sexto momento que surge o edifício que servirá de casa de residência dos guarda-fios e estação de correios da vila de Alcoutim.

A partir de meados do século XX acrescenta-se ao corpo arquitectónico existente o compartimento das instalações sanitárias e a ligação de esgotos à rede de saneamento básico público, assim como a criação do nível de circulação em grés hidráulico nos compartimentos 2, 4, 5 e 7. Neste último compartimento, espaço de cozinha, construíram-se bancadas de apoio e uma zona de fogo com chaminé (Figura 3 ). Já no final do século XX e inícios do século XXI ocorre a reconstrução dos prédios vizinhos com serventia pelo Largo do Castelo.

\section{ESPÓLIO ARQUEOLÓGICO}

A caracterização do espólio foi organizada em dois momentos principais.

Ao primeiro momento, correspondente aos contextos mais antigos de construção, uso e desactivação, dos séculos XV-XVI, contam-se alguns numismas, nomeadamente seis moedas portuguesas, onde se identificaram três ceitis de $\mathrm{D}$. Afonso $\mathrm{V}$, um ceitil de D. João II, um ceitil de D. Manuel I e um dinheiro de D. Afonso III.

Relativamente ao espólio cerâmico deste primeiro momento, este conjunto é composto, maioritariamente, por cerâmica comum vermelha, de pastas porosas, com abundantes materiais não plásticos e cozeduras oxidantes. Neste grupo destacam-se as caçoilas e as frigideiras, em alguns casos vidradas em melado no seu interior.

No segundo momento, cronologicamente atribuído aos finais do século XIX e ao início do XX, foram identificados materiais datados entre os séculos XVII a XX.

De forma geral, estão associadas a este segundo momento produções de cerâmica de cozinha, comum e vidrada no seu interior, nomeadamente caçoilas, de cerâmica vidrada polícroma, onde se salientam pratos, palanganas e malgas, da chamada faiança popular de Coimbra (Figura 7) ou louça de "Ratinhos" (Pereira, 1998). Existe também neste grupo cerâmica vidrada decorada com temas impressos, onde nalguns fragmentos se consegue distinguir uma produção de Sacavém.

Destaca-se, também, a recolha de duas safras em 
osso (Figura 8), de faces aplanadas, onde se observam uma série de incisões, que resultam do processo de "picar foicinhas" de gume serrilhado (Moreno-García, Pimenta \& Ruas, 2005, pp. 571-574).

De referir, em relação aos materiais metálicos, que os mais significativos se tratam de nove projécteis de pirobalística em ferro, quatro moedas espanholas (dois maravedis de D. Filipe IV e dois maravedis de D. Carlos IV), e, por fim, objectos de adorno do quotidiano, como, por exemplo, dois botões de punho com decoração fitomórfica (Figura 9).

Também foram recolhidos testemunhos do uso deste espaço como residência dos guarda-fios e estação dos CTT, como foi o caso de diferentes isoladores telegráficos, em porcelana, e um selo de chumbo, do tipo "bula" (Sousa, 2016, pp. 8), que apresenta pequenos orifícios para a passagem de um cordel nas suas extremidades e onde se percebe, numa das faces, o escudo monárquico português e, na outra face, se lê: "Correios de Lisboa" (Figura 10).

\section{CONSIDERAÇÕES FINAIS}

Estes trabalhos permitiram compreender que, pelo menos, a partir do século XV se registam construções nesta zona do perímetro urbano da vila de Alcoutim, assim como a existência do antigo arruamento das Portas de Tavira, actual R. D. Sancho II (Gradim, 2006, pp. 47 e 66).

O edificado detectado, por se situar em zona de encosta, organizou-se sobre plataformas / patamares de natureza antrópica e as técnicas construtivas adoptadas sugerem uma economia de recursos. Dentro das opções identificadas encontrámos alvenarias de pedra local, cujo ligante podia ser em terra ou argamassa, taipas, tijolos de adobe e cerâmicas de construção, tais como ladrilhos, telhas de canudo ou tijolos maciços.

Esta economia de recursos também foi verificada no caso concreto do canto Norte do edifício dos Antigos CTT (Fig. 3). Aqui existiram dois espaços construídos sobre os entulhos nivelados de ocupações anteriores, entretanto abandonadas / desactivadas. Relativamente ao espólio arqueológico recolhido, este abrange um arco temporal, de forma genérica, balizado entre os séculos XIV ao XX, onde se exceptua um numisma recolhido na sondagem $I$ (Fig. 3), classificado como um dinheiro de Afonso III (Vaz, 1969, pp. 101-105). Como tal, suspeita-se que, imediatamente antes da fundação do castelo por
D. Dinis, existisse aqui um pequeno aglomerado populacional.

Outro dado relevante observado foi a recolha de vários projécteis pirobalísticos em ferro, de diferentes nódulos de escórias de ferro e de vidro, assim como a identificação de quatro fossas de despejo de resíduos associados à actividade de uma forja nas cercanias. Estes dados, associados à recolha de duas safras de osso, parecem indicar a existência de ferreiros, ligados à produção de alfaias agrícolas (Moreno-García, Pimenta \& Ruas, 2005, p. 574) e / ou de utensílios pirobalísticos.

\section{BIBLIOGRAFIA}

ALMEIDA, João de (1943) - Reprodução anotada do Livro das Fortalezas de Duarte d'Armas. Lisboa: Editorial Império.

BORRALHO, António Gonçalves (2015) - O Transporte de Correio por Caminho de Ferro. O Mensageiro do Algarve. Faro. Ano III, 9, pp. 3-17.

CATARINO, Helena (1994) - Arqueologia Medieval no Algarve Oriental. Os Castelos de Alcoutim. In Arqueología en el entorno del Bajo Guadiana, Encuentro Internacional de Arqueología del sudoeste. Huelva: Grupo de Investigación Arqueológica del Patrimonio del Suroeste, Universidad de Huelva, pp. 657-671.

CATARINO, Helena (1997/1998) - O Algarve Oriental Durante a Ocupação Islâmica. Povoamento rural e recintos fortificados. al-ưlyã. Loulé. 6, 3 vols.

CATARINO, Helena (2003) - Cerâmicas da Baixa Idade Média e de inícios do período moderno registadas no caste-

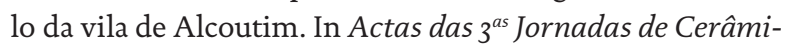
ca Medieval e Pós-Medieval. Tondela: Câmara Municipal de Tondela. pp. 161-177.

GRADIM, Alexandra (2006) - Alcoutim Urbano e Rural. Dos finais da Idade Média ao fim do antigo regime. Lisboa: Edições Colibri / Câmara Municipal de Alcoutim.

GRADIM, Alexandra (2008) - Os condes Meneses e a vila moderna de Alcoutim. In al Gharb, Revista Cultural do Algarve. Olhão: Gente Singular, pp. 38-44.

MAGALHÃES, Natércia (2008) - Algarve: Castelos, Cercas e Fortalezas. Faro: Letras Várias, Edições e Arte.

MORENO-GARCÍA, Marta; PIMENTA, Carlos M.; RUAS, José Paulo (2005) - Safras em osso para picar foicinhas de gume serrilhado... a sua longa história. Revista Portuguesa de Arqueologia. Lisboa. 8-2, pp. 571-627.

NUNES, António Miguel Ascensão (1985) - Alcoutim: Capital do Nordeste Algarvio (Subsídios para uma Monografia). Alcoutim: Câmara Municipal de Alcoutim. 
PEREIRA, João Castel-Branco, coord. (1998) - Os Ratinhos, Faiança Popular de Coimbra. Lisboa: IPM / Museu Nacional do Azulejo.

SOUSA, José de (2016) - Selos de Chumbo. Os testemunhos dos intercâmbios comerciais e de controlo fiscal no Algarve, do século XV ao século XIX. Portimão: Associação Projecto IPSIIS.

VAZ, Joaquim Ferraro (1969) - Livro das Moedas Portuguesas. I. Braga: Livraria Cruz.

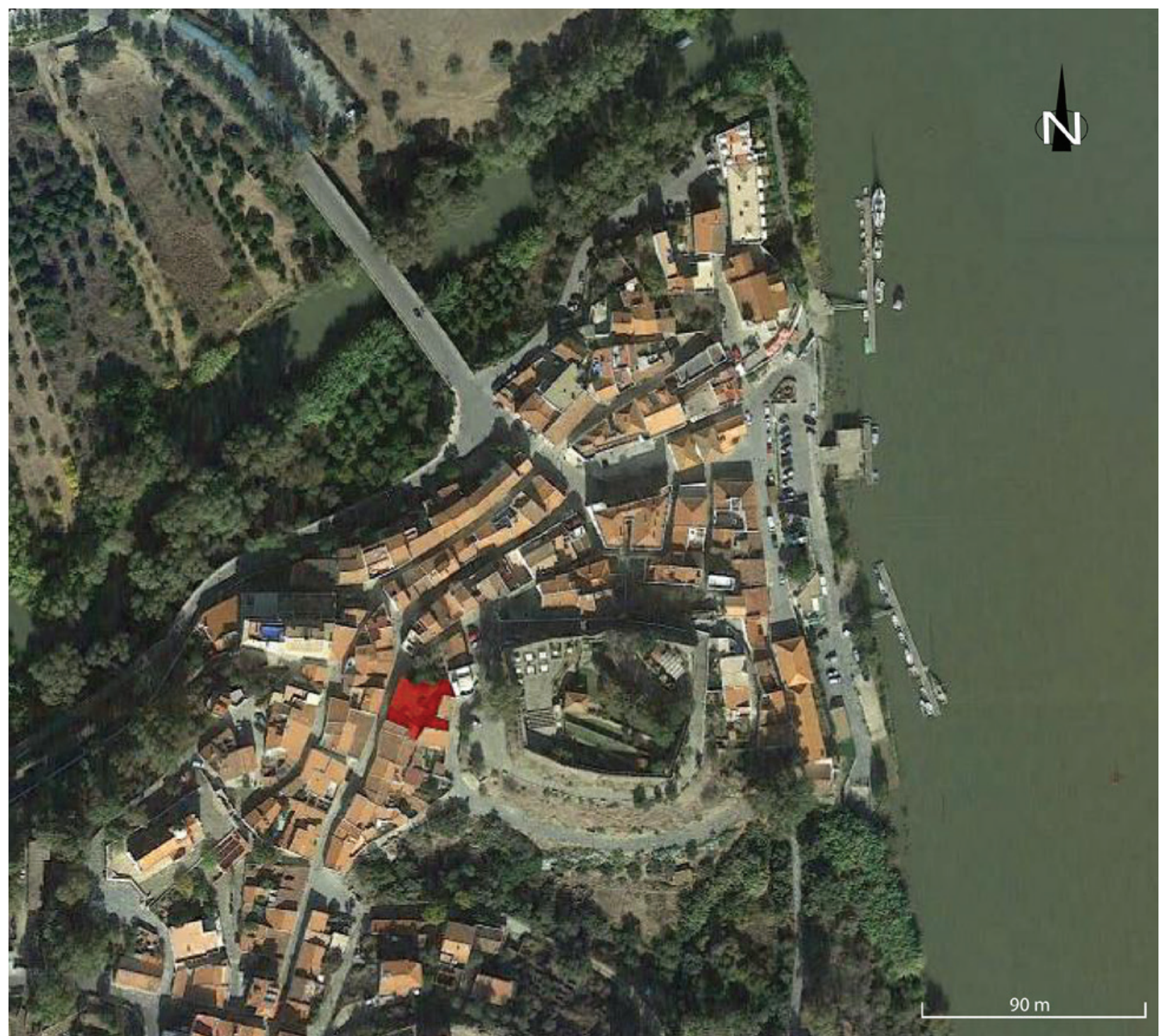

Figura 1 - Localização do imóvel dentro do perímetro urbano da vila de Alcoutim, assinalado a vermelho. 


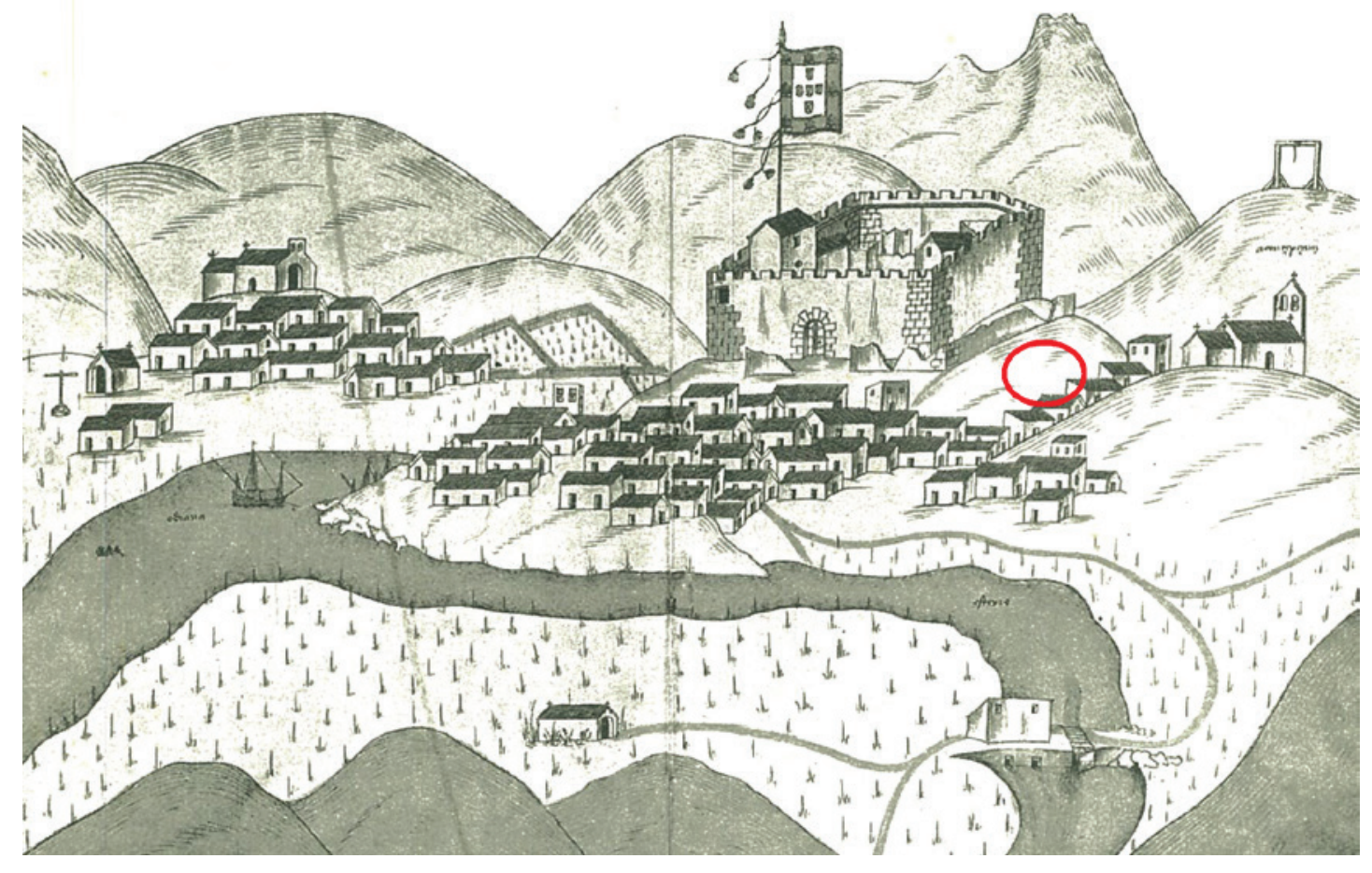

Figura 2 - Vista desde o lado Norte de Alcoutim, por volta de 1509 (Livro das Fortalezas, Duarte d'Armas), com localização da área do edifício dos Antigos CTT assinalada a vermelho.

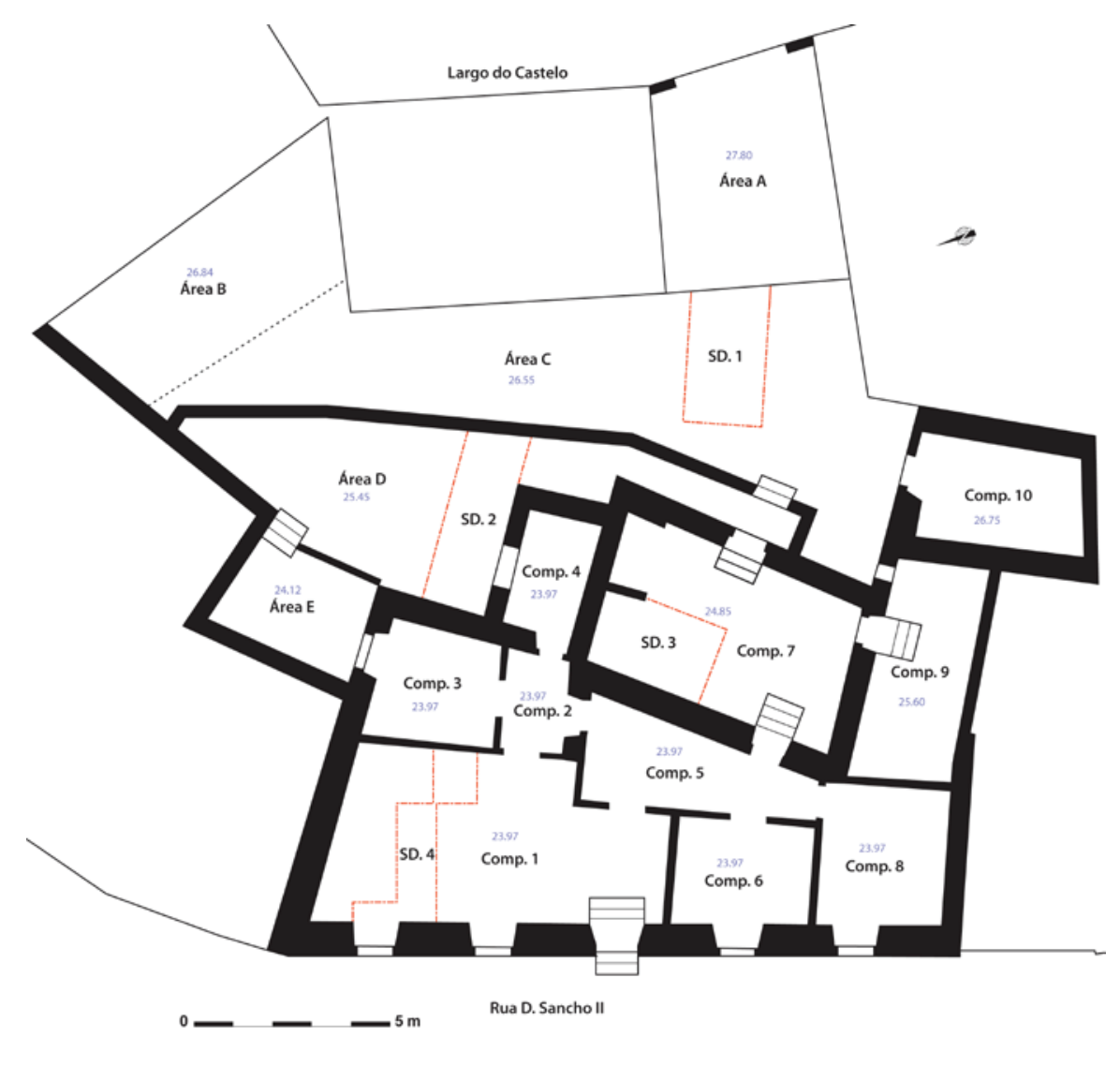

Figura 3 - Localização das sondagens, áreas e compartimentos no levantamento do edifício dos Antigos CTT de Alcoutim. 


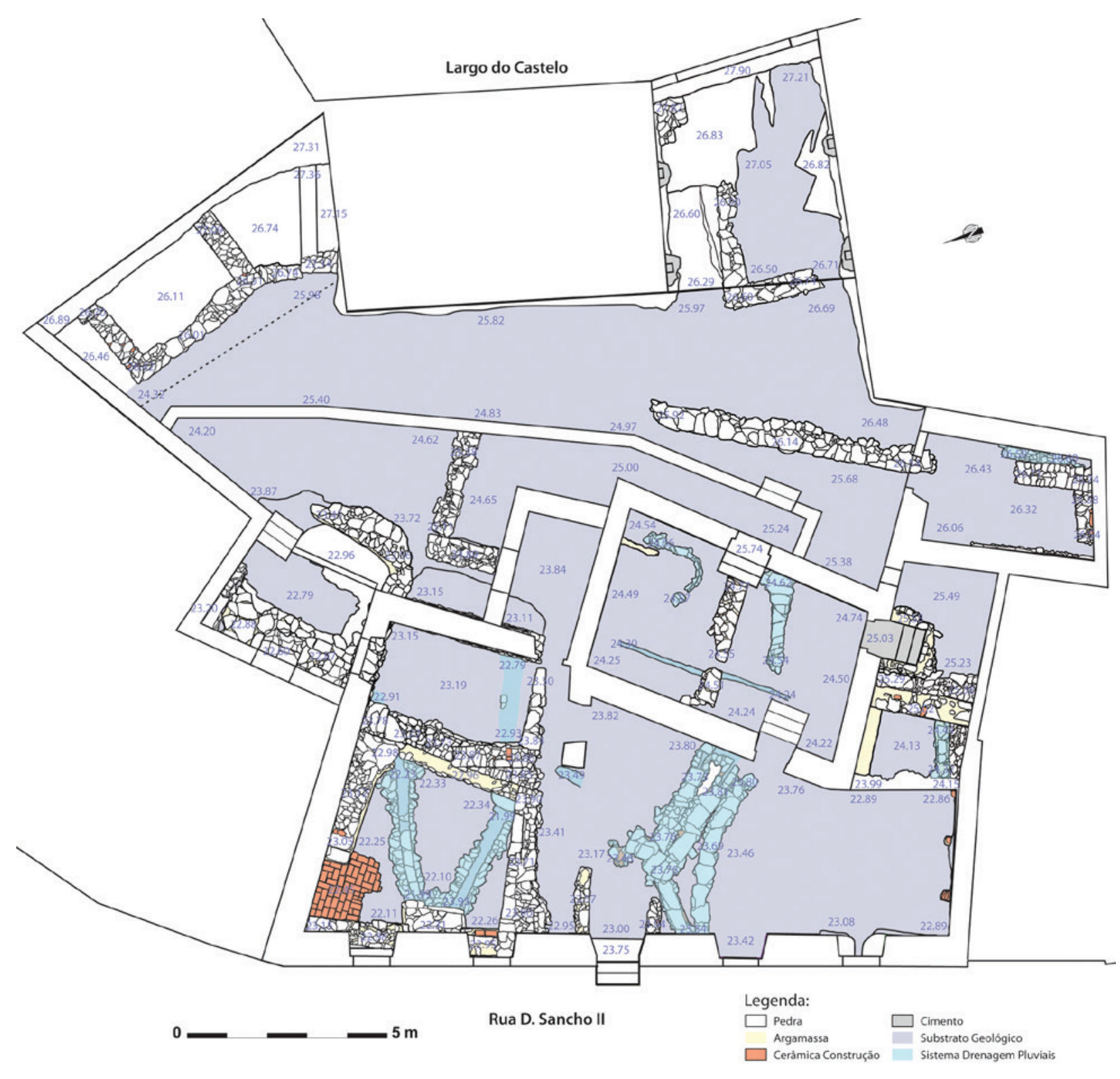

Figura 4 - Planta geral com o edifício pré-existente e as principais estruturas arqueológicas identificadas durante os trabalhos. 


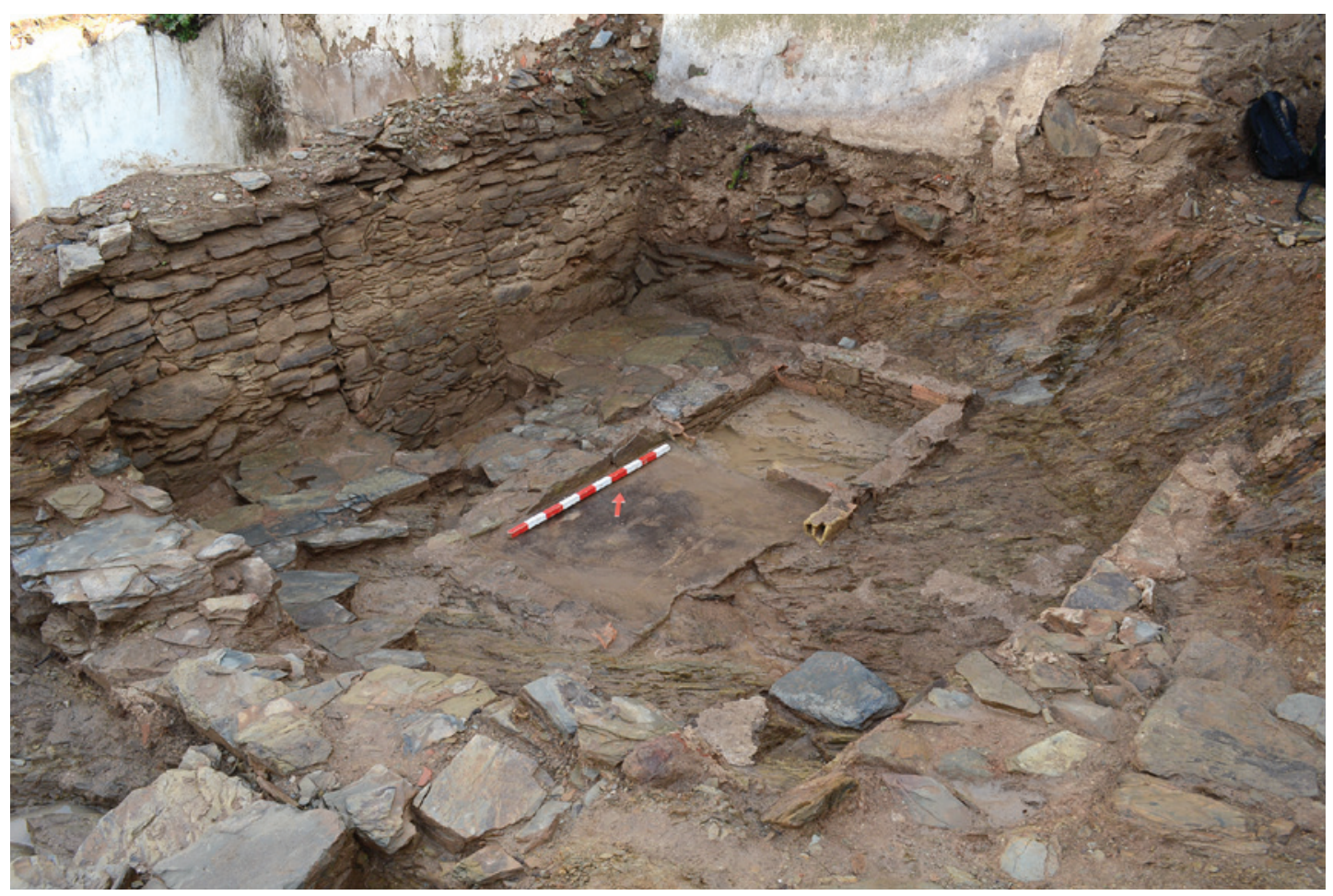

Figura 5 - Aspecto geral do ambiente mais antigo identificado na área E. No lado esquerdo o vão de acesso à casa de entrada, entaipado durante a fase IV, e outro vão de porta, à direita, na direção do terreno vizinho Norte.

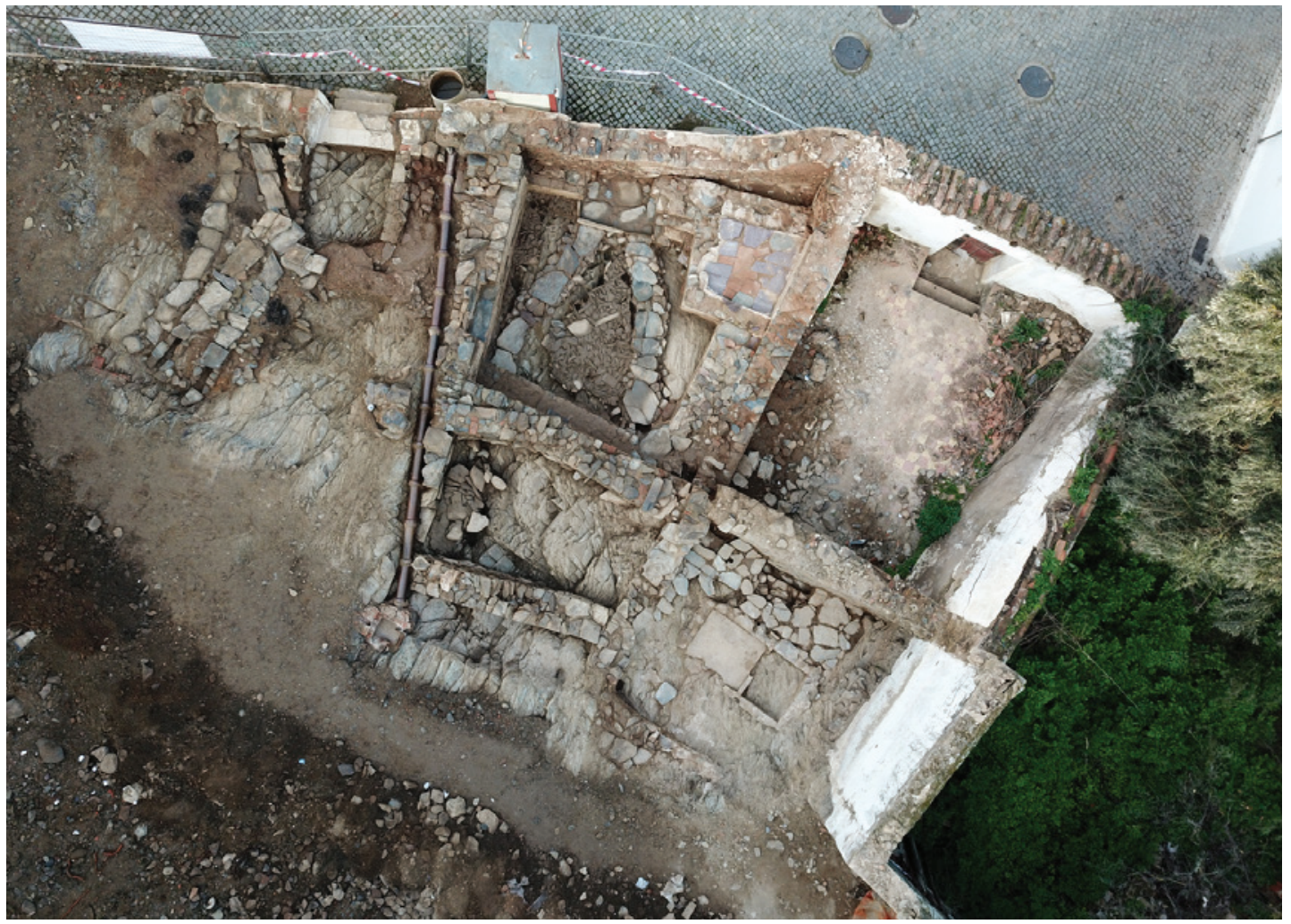

Figura 6 - Vista aérea sobre os contextos arqueológicos identificados na zona Noroeste do empreendimento (Fotografia de Alexandra Gradim / João Carlos Simões). 


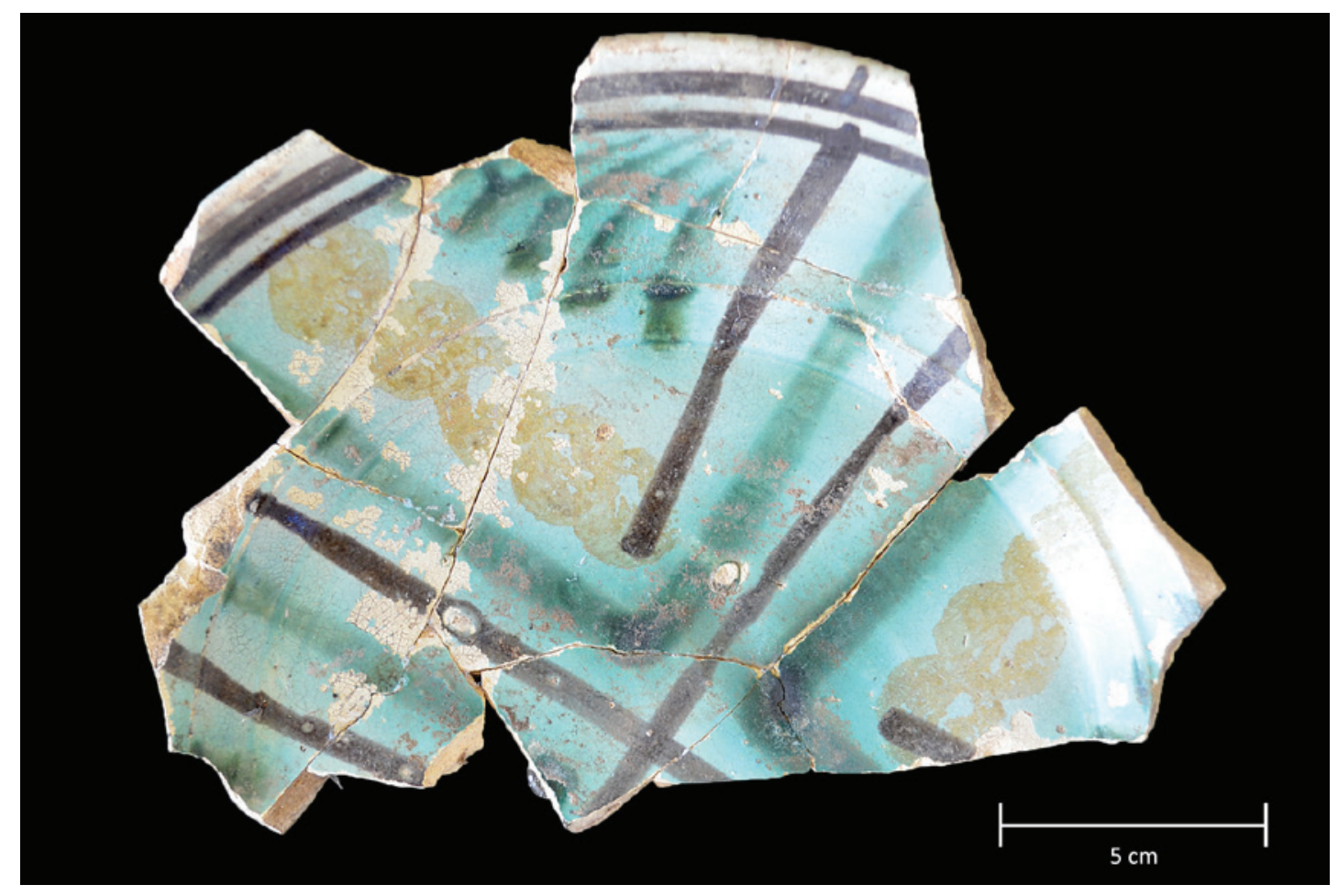

Figura 7 - Prato de faiança popular de Coimbra ou louça de "Ratinhos".

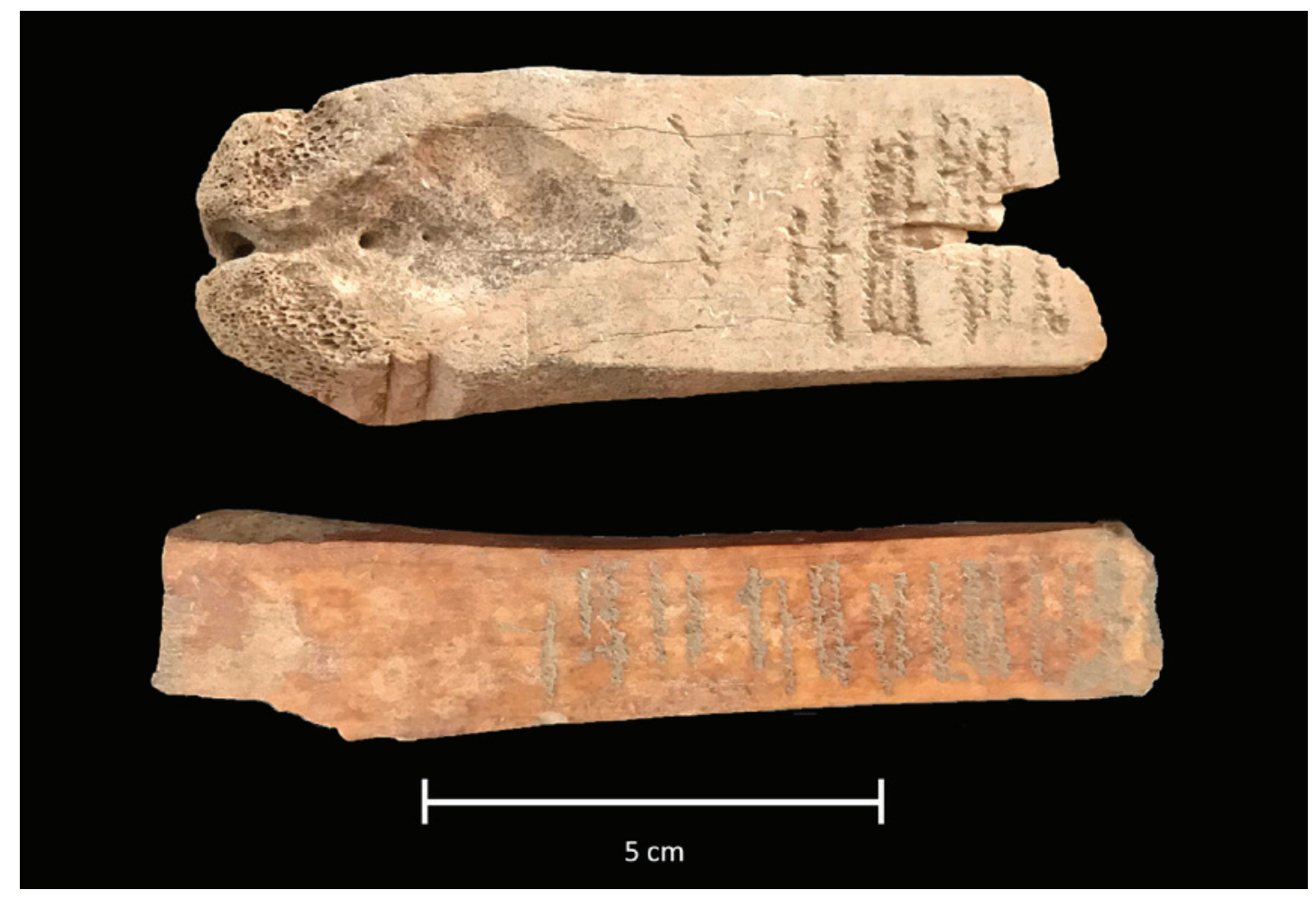

Figura 8 - Safras em osso. 


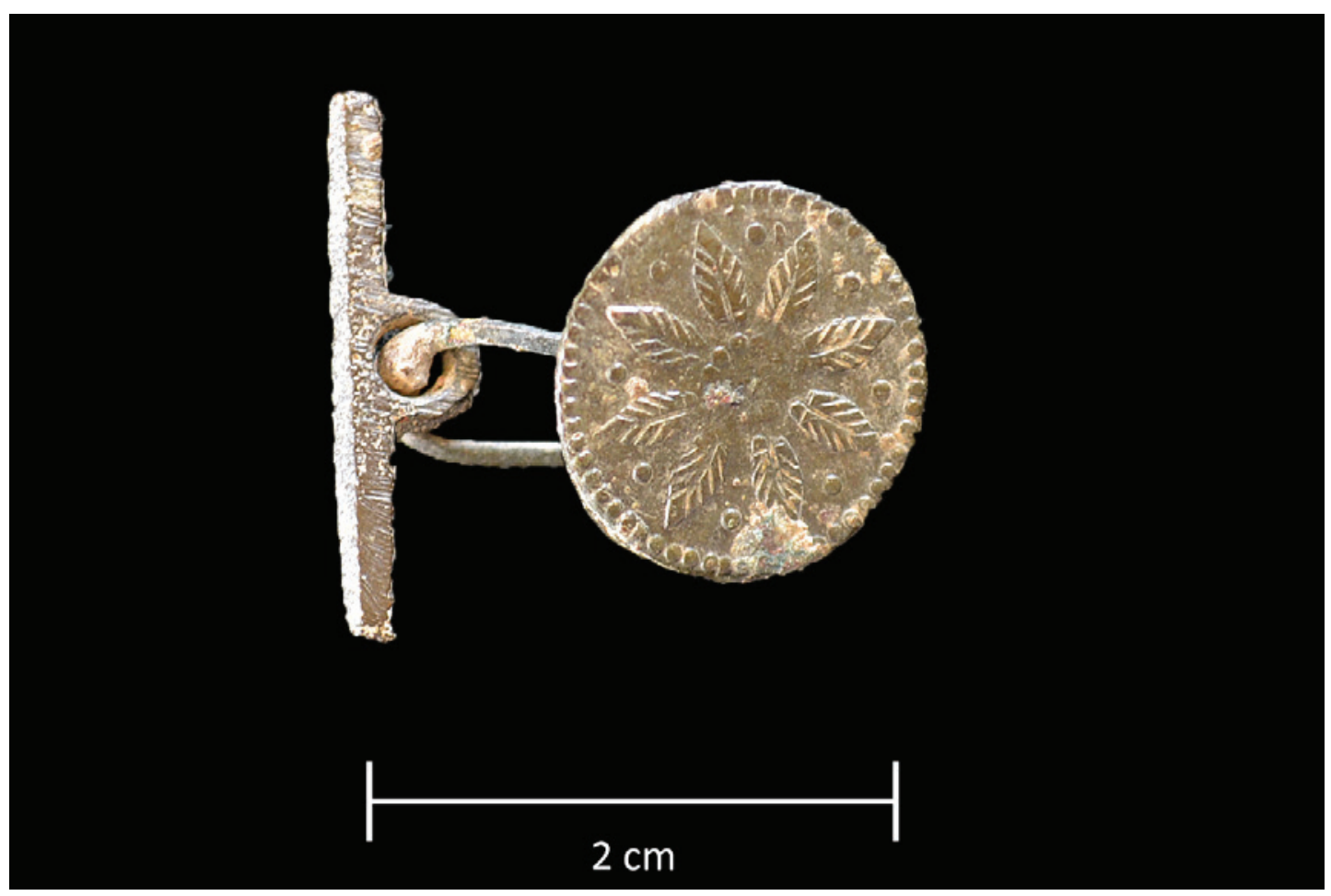

Figura 9 - Botão de punho com decoração fitomórfica.

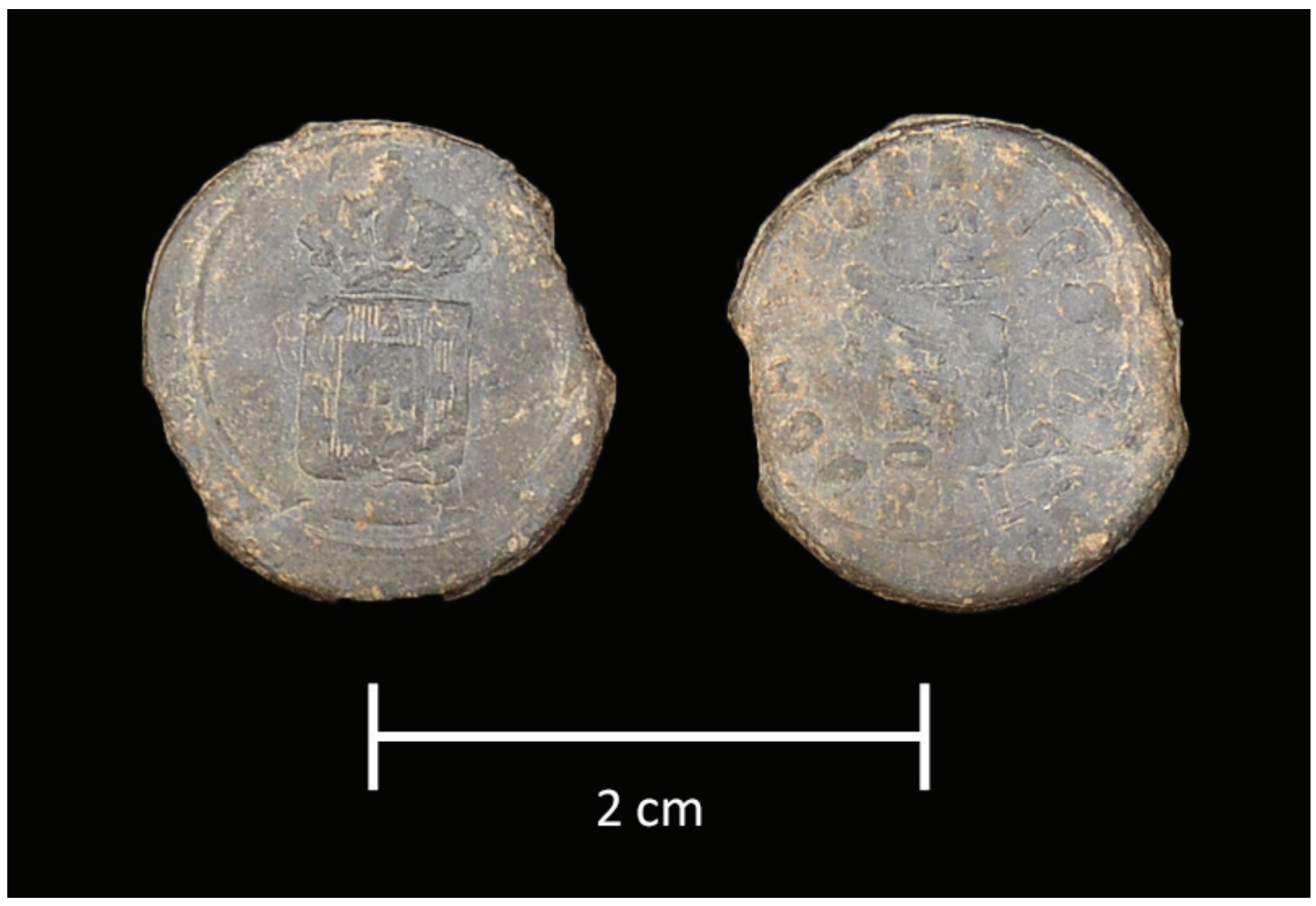

Figura 1o - Selo em chumbo, do tipo “bula” (século XIX a inícios do século XX). 


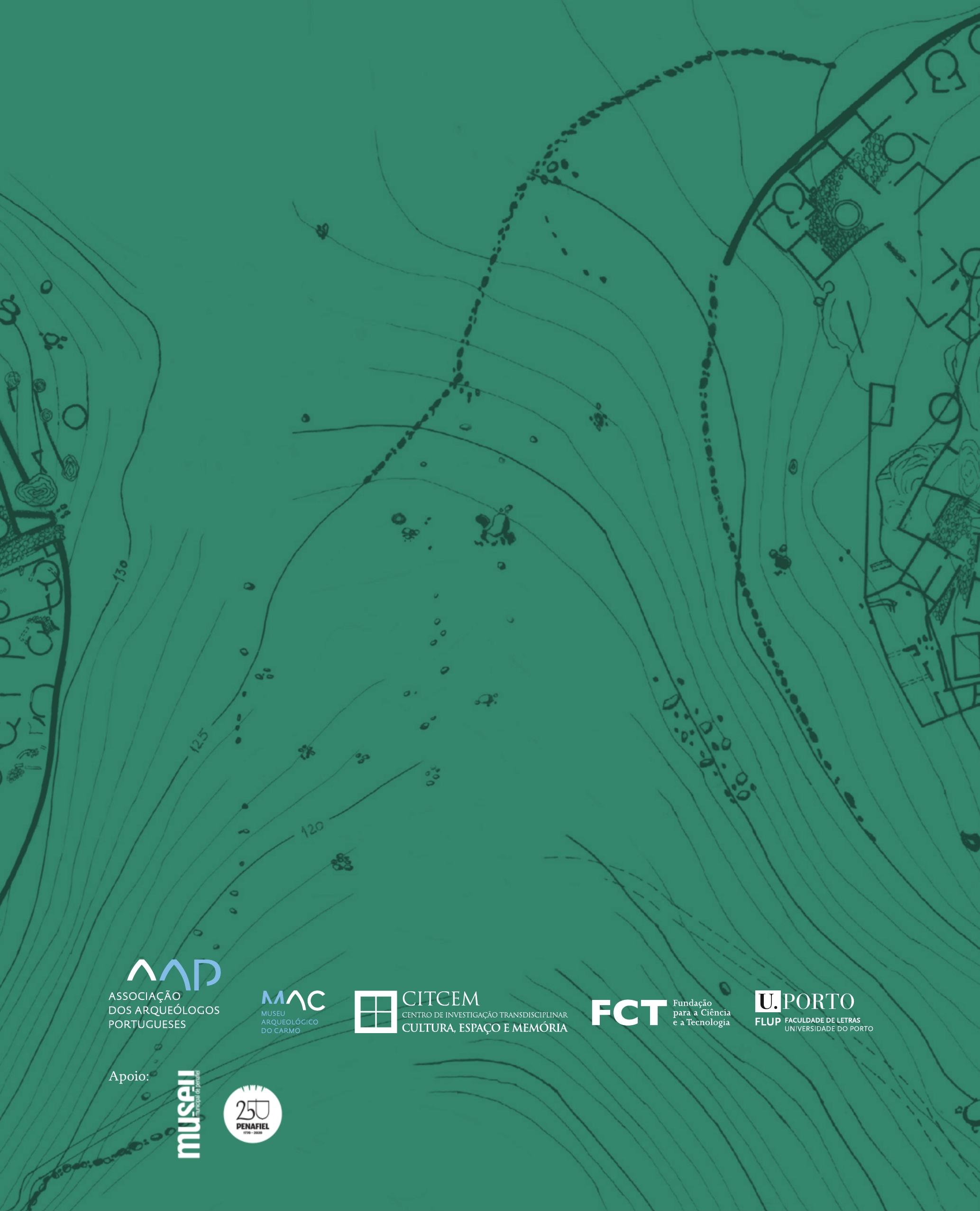

